\title{
Quantitative Analysis of Reactive Oxygen Species Photogenerated on Metal Oxide Nanoparticles and Their Bacteria Toxicity: The Role of Superoxide Radicals
}

\author{
Dan Wang, ${ }^{\dagger,+}$ Lixia Zhao, ${ }^{* \dagger \odot ~ H a i y a n ~ M a, ~}{ }^{\dagger, \dagger}$ Hui Zhang, ${ }^{\dagger}$ and Liang-Hong Guo ${ }^{* \dagger}$ \\ ${ }^{\dagger}$ State Key Laboratory of Environmental Chemistry and Ecotoxicology, Research Center for Eco-Environmental Sciences, Chinese \\ Academy of Sciences, P.O. Box 2871, 18 Shuangqing Road, Beijing 100085, P.R. China \\ ${ }^{\ddagger}$ University of Chinese Academy of Sciences, Beijing 100049, P.R. China
}

\section{Supporting Information}

\begin{abstract}
Ecotoxicity of engineered nanoparticles (NPs) has become the focus of considerable attention because of their wide applications. Reactive oxygen species (ROS) play important roles in the toxicity mechanisms of engineered metal oxide NPs. This work aimed to understand quantitatively the contribution of photogenerated ROS on metal oxide NPs to their toxicity. The dynamic generation of $\mathrm{O}_{2}{ }^{--},{ }^{\bullet} \mathrm{OH}$, and $\mathrm{H}_{2} \mathrm{O}_{2}$ in aqueous suspensions of photoilluminated metal oxide nano- and bulk particles $\left(\mathrm{TiO}_{2}, \mathrm{ZnO}\right.$, $\mathrm{V}_{2} \mathrm{O}_{5}, \mathrm{CeO}_{2}, \mathrm{Fe}_{2} \mathrm{O}_{3}$, and $\mathrm{Al}_{2} \mathrm{O}_{3}$ ) was measured by a continuous-flow chemiluminescence (CFCL) detection system. Superoxides were generated on all six nanoparticles as well as bulk $\mathrm{TiO}_{2}$ and $\mathrm{ZnO}$, with nano $\mathrm{TiO}_{2}$ producing the highest concentration $(180 \mathrm{nM})$.

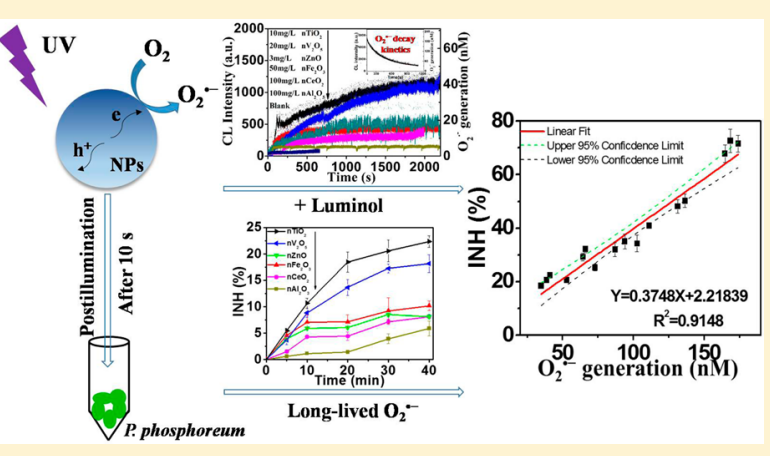
Hydroxyl radicals were detected on both nano- and bulk $\mathrm{TiO}_{2}$ and $\mathrm{ZnO}$, whereas $\mathrm{H}_{2} \mathrm{O}_{2}$ was detected only on $\mathrm{TiO}_{2}$ and $\mathrm{ZnO}$ nanoparticles. The generation of ROS can in general be interpreted by the electronic structures and surface defects of the NPs and the ROS redox potentials. Furthermore, acute toxicity of the six metal oxide particles to a luminescent bacterium, $P$. phosphoreum 502 was assessed after photoillumination. The toxicity effect was attributed to the long-lived $\mathrm{O}_{2}{ }^{\bullet-}$ radicals on the nanoparticlce, and its potency follows the order of $\mathrm{TiO}_{2}>\mathrm{ZnO}>\mathrm{V}_{2} \mathrm{O}_{5}>\mathrm{Fe}_{2} \mathrm{O}_{3}>\mathrm{CeO}_{2}>\mathrm{Al}_{2} \mathrm{O}_{3}$, which is the same as the order of the $\mathrm{O}_{2}{ }^{\bullet-}$ concentration measured by CFCL. Our work revealed quantitatively the important role superoxide radicals play in the toxicity of various metal oxide nanoparticles after photoillumination.
\end{abstract}

\section{INTRODUCTION}

With the development of the global nanotechnology market, engineered nanoparticles are being mass produced rapidly because of their diverse applications in various industries, research, wastewater treatment, and daily necessities. ${ }^{1}$ Among such nanoparticles, metal oxide nanoparticles (NPs) are of economic importance because of their steady increase in nanotechnology applications. ${ }^{2}$ For example, NPs of $\mathrm{TiO}_{2}$ and $\mathrm{ZnO}$ are regularly used in cosmetics, sunscreens, ${ }^{3}$ solar-driven self-cleaning coatings, ${ }^{4}$ and textiles. ${ }^{5}$ Further, $\mathrm{TiO}_{2}$ is a useful photocatalyst for degrading many organic contaminants and microorganisms in water and air, ${ }^{6}$ and $\mathrm{ZnO}$ and $\mathrm{TiO}_{2}$ have also been used as antibacterial agents in dentistry. ${ }^{7}$ However, the large-scale production and use of metal oxide NPs will eventually intensify their release into natural environments such as water, soil, and air via manufacturing effluents or spills during handling and shipping. Therefore, concerns about their potential environmental and ecological risks are garnering widespread attention.

Microorganisms, especially bacteria, are usually adopted as a surrogate to predict nanotoxicity to humans and ecosystems because of their role in elemental biogeochemical cycling. In this regard, several metal oxide NPs such as $\mathrm{TiO}_{2}$ have been reported to possess significant toxicity toward bacteria. ${ }^{8-11}$ Other metal oxide $\mathrm{NPs}$, such as $\mathrm{ZnO}, \mathrm{CeO}_{2}$, etc., also exhibit toxicity to various bacteria including Escherichia coli, Bacillus subtilis, Streptococcus aureus, and photobacteria. ${ }^{12-14}$ The toxicity of metal oxide NPs is frequently attributed to reactive oxygen species (ROS) and consequent ROS-induced damage. ${ }^{15}$ In particular, many studies have reported the photogeneration of ROS on the surfaces of metal oxide NPs. ${ }^{16}$ The general principle of ROS formation is that electron $\left(\mathrm{e}_{\mathrm{cb}}{ }^{-}\right) /$hole $\left(\mathrm{h}_{\mathrm{vb}}{ }^{+}\right)$ pairs are generated in the bulk when metal oxide NPs are illuminated by light with energy equal to or greater than their band gap energy. These charge carriers migrate to the NP surfaces and react with oxygen or water to produce ROS. ${ }^{16}$ The reactivity of some ROS is high enough to damage virtually all types of biomolecules. For instance, the oxidation potential of hydroxyl radical $\left({ }^{\bullet} \mathrm{OH}\right)$ is $2.78 \mathrm{~V}$, which can nonselectively

Received: February 10, 2017

Revised: June 16, 2017

Accepted: July 12, 2017

Published: July 12, 2017 
damage carbohydrates, nucleic acids, lipids, proteins, DNA, and amino acids. ${ }^{17}$ Bakalova et al. ${ }^{18}$ and Wang et al. ${ }^{19}$ reported that singlet oxygen $\left({ }^{1} \mathrm{O}_{2}\right)$ is the main mediator of photocytoxicity and can cause biomembrane oxidation and degradation. As a precursor to both ${ }^{\bullet} \mathrm{OH}$ and ${ }^{1} \mathrm{O}_{2}$, Fridovich ${ }^{20}$ has reported that superoxide ions $\left(\mathrm{O}_{2}{ }^{\bullet-}\right)$ have significant biological implications. Although many previous studies have investigated whether ROS generation is responsible for oxidative stress induced by NPs, the fundamental mechanism underlying the process has not been well established. For example, Zhang et al. ${ }^{21}$ explored whether the diffusion of ${ }^{\bullet} \mathrm{OH}$ played an important role in the photocatalytic disinfection of E. coli K-12. Chen's group ${ }^{22,23}$ reported that the total generation of $\mathrm{ROS}$ (i.e., ${ }^{1} \mathrm{O}_{2},{ }^{\circ} \mathrm{OH}$, and $\mathrm{O}_{2}^{\bullet-}$ ) was linearly correlated with antibacterial effects. Sawai et al. $^{24}$ reported that active oxygen species such as $\mathrm{O}_{2}{ }^{\bullet-}$ generated from metal oxide powders were one of the primary factors that caused antibacterial activity. Therefore, the exact roles of ROS remain unclear, which may be attributed to a lack of data concerning the formation kinetics of ROS and their lifetimes. In additional, regarding the toxicity risk assessment of wide band gap oxides, the metal oxide is usually mixed with bacteria and then irradiated by UV light, which is followed by measuring the photocatalytic antibacterial activity. ${ }^{8-14}$ Little is known about whether ROS contribute to toxicity as bound species on the NP surface or as diffusive species in the solution. The role of longlived radicals in the toxic effect of these metal oxides has not been fully characterized.

Herein, the dynamic generation of ROS (i.e., $\mathrm{O}_{2}^{\bullet-},{ }^{\bullet} \mathrm{OH}$, and $\mathrm{H}_{2} \mathrm{O}_{2}$ ) was quantified and compared for six common types of metal oxide NPs $\left(\mathrm{nTiO}_{2}, \mathrm{nZnO}, \mathrm{nCeO}_{2}, \mathrm{nV}_{2} \mathrm{O}_{5}, \mathrm{nFe}_{2} \mathrm{O}_{3}\right.$, and $\mathrm{nAl}_{2} \mathrm{O}_{3}$ ) using the continuous flow chemiluminescence (CFCL) methods developed in our laboratory. ${ }^{16,25}$ These metal oxide NPs were chosen because of their broad application in industrial products. To elucidate the effect of primary particle size on ROS generation, the bulk counterparts of these NPs were also quantified. The formation of ROS was analyzed viz. the metal oxide band energy structures and the ROS redox potentials. The $\mathrm{O}_{2}{ }^{--}$decay process on the surface of the postillumination NPs was also measured, which showed that $\mathrm{O}_{2}{ }^{\bullet-}$ is relatively stable with a long lifetime. In order to understand the role of long-lived $\mathrm{O}_{2}^{\bullet-}$ on the toxic effects of these NPs, acute toxicity of these NPs toward using Photobacterium phosphoreum ( $P$. phosphoreum) 502 was evaluated. We found that the toxicity effect increased significantly when $P$. phosphoreum 502 was exposed to NPs after photoillumination and the potency correlated closely with the concentration of $\mathrm{O}_{2}^{\bullet-}$ species measured by CFCL. This investigation provides new insights into the roles of long-lived radicals on effecting metal oxide NPs phototoxicity.

\section{EXPERIMENTAL SECTION}

Chemicals and Materials. All metal oxide NPs and their bulk counterparts, the capture probes of ROS including phthalhydrazide (Phth), 5-amino-2,3-dihydro-1,4-phthalazinedione (luminol), terephthalic acid (TA), and 3-bis(2-methoxy4-nitro-5-sulfophenyl)-2 $\mathrm{H}$-tetrazolium-5-carboxanilide (XTT), and their scavengers superoxide dismutase (SOD), isopropanol, and glycerol were purchased from Sigma-Aldrich (St. Louis, $\mathrm{MO})$. Bis(hydrogenperiodato)cuprate(III) $\left[\mathrm{K}_{5} \mathrm{Cu}\left(\mathrm{HIO}_{6}\right)_{2}\right]$ $(\mathrm{Cu}(\mathrm{III}))$ was synthesized according to a previously published methodology. ${ }^{26}$ P. phosphoreum (502 mutation) was purchased from Hamamatsu Photon Techniques Inc. (Beijing, China). $\mathrm{NaCl}, \mathrm{Na}_{2} \mathrm{HPO}_{4} \cdot 12 \mathrm{H}_{2} \mathrm{O}$, and $\mathrm{KH}_{2} \mathrm{PO}_{4}$ were obtained from
Sinopharm Chemical Reagent Co. (Shanghai, China). Yeast extract and tryptone were obtained from Oxoid (Basingstoke, England). All other chemicals used in this study were obtained from commercial sources as guaranteed-grade reagents without further purification.

Characterization of NPs and Their Bulk Counterparts. All metal oxide NPs and their bulk counterparts were visualized using a Hitachi H-7500 transmission electron microscope (TEM). The microscope was operated in the bright field mode at an acceleration voltage of $80 \mathrm{kV}$. The hydrodynamic size and zeta potential of these particles in aqueous suspensions were characterized by dynamic light scattering (DLS) on a Zetasizer Nano ZS instrument (Malvern Instruments, UK). Table S1 summarizes the particle properties, and Figure S1 shows TEM images of various Metal-oxide NPs.

Photochemical Experiments. The online detection of ROS generated from UV irradiation of the semiconductor nanoparticle suspension and its acute toxicity assessment were performed using a modified CL apparatus. The key components of the apparatus included a photoreactor and a computer-controlled CL analyzer (Institute of Biophysics, Chinese Academy of Sciences, Beijing, China). For the online detection of ROS generation, the CFCL experiment was performed in which a cylindrical quartz container $(100 \mathrm{~mL})$ and two glass containers $(200 \mathrm{~mL})$ were used for the photoreactor and chemical reagents, respectively. The three containers were connected separately to the peristaltic pumps through Tygon pump tubing (i.d. $1 \mathrm{~mm}$ ) (detailed in Figure S2) ${ }^{16}$ For the toxicity test, the batch CL experiments were carried out as shown in Figure S3. All samples, including the metal oxide NPs and the nanoparticle mixture with $P$. phosphoreum, were irradiated with a 500-W xenon light source (Beijing Trusttech Technology Co. Ltd., Beijing, China) with a $365 \pm 9 \mathrm{~nm}$ band-pass filter, and the intensity in the center of the aqueous suspension was approximately $1.1 \mathrm{~mW} / \mathrm{cm}^{2}$, as measured by a UVX radiometer (Photoelectric Instrument Factory of Beijing Normal University, Beijing, China). Fluids were injected into the detection cell in the CL analyzer, and the $\mathrm{CL}$ intensity was measured with a photomultiplier tube (PMT).

Dynamic Detection of $\mathrm{O}_{2}{ }^{--}, \cdot \mathrm{OH}$, and $\mathrm{H}_{2} \mathrm{O}_{2}$. The ROSs detection was carried out using our previously published method which has been validated with the conventional methods. ${ }^{16}$ For $\mathrm{O}_{2}{ }^{\bullet-}$, luminol was used as a $\mathrm{CL}$ indicator. 50 $\mu \mathrm{M}$ luminol and the illuminated metal oxide particle suspension were mixed through the three-valve system before the solution entered the detection cell. The CL intensity in the cell was then measured by the PMT. In the CFCL apparatus, it took approximately $10 \mathrm{~s}$ for the metal oxide particle suspension to flow from the photoreactor to the detection cell. The lifetimes of ${ }^{\bullet} \mathrm{OH}(200 \mu \mathrm{s})$ and ${ }^{1} \mathrm{O}_{2}(2 \mu \mathrm{s})$ are very short, whereas that of $\mathrm{O}_{2}{ }^{\bullet-}$ ( 5 to hundreds of seconds) is relatively long, and $\mathrm{H}_{2} \mathrm{O}_{2}$ is very stable. ${ }^{18,19}$ Therefore, only $\mathrm{O}_{2}{ }^{--}$and $\mathrm{H}_{2} \mathrm{O}_{2}$ may reach the detection cell. Experiments confirmed that, without an oxidant such as ferricyanide, luminol produced very little $\mathrm{CL}$ when it reacted with micromolar quantities of $\mathrm{H}_{2} \mathrm{O}_{2}$. Hence, if the metal oxide particle suspensions were mixed with luminol immediately prior to entering the detection cell, the only ROS to react with the probe to produce CL would be $\mathrm{O}_{2}{ }^{\bullet-}$.

For ${ }^{\bullet} \mathrm{OH}, 20 \mu \mathrm{M}$ Phth was added to the metal oxide particle suspensions in the photoreacter to specifically capture ${ }^{\bullet} \mathrm{OH}$, and was converted to 5-OH-Phth. The latter acted as a stable CL reagent and emitted strong CL when mixed with $50 \mu \mathrm{M}$ 

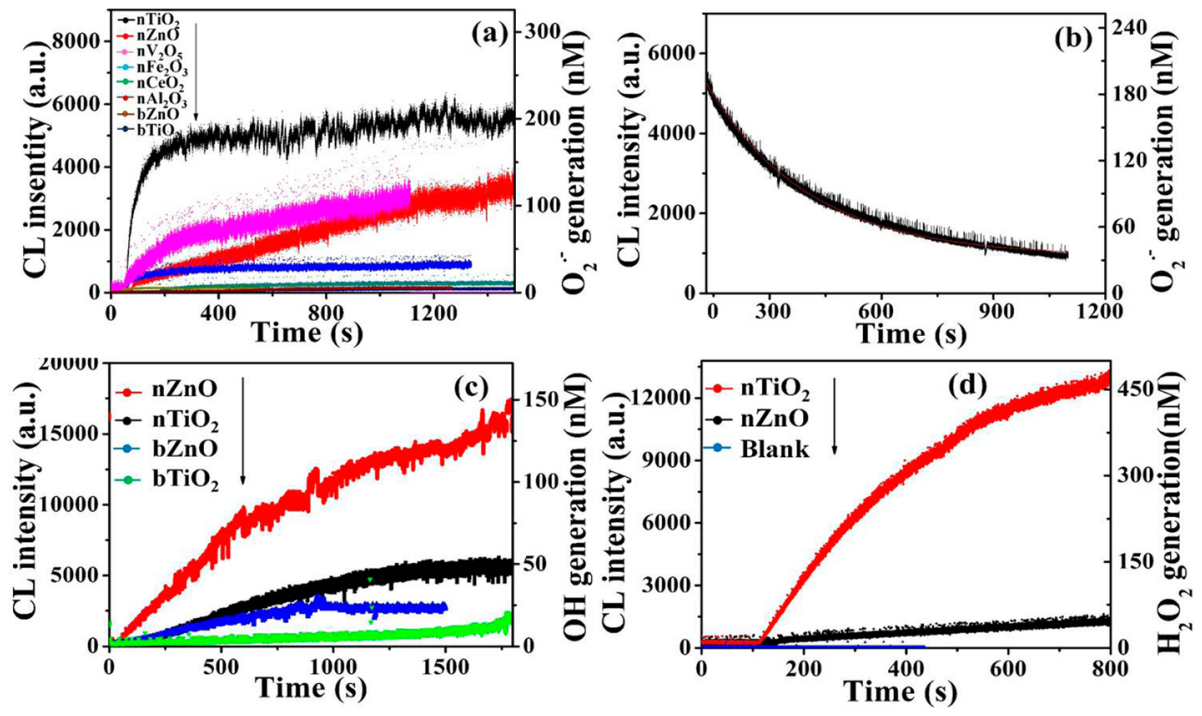

Figure 1. (a) $\mathrm{O}_{2}{ }^{--}$generation kinetics of various NPs and their bulk counterparts under UV irradiation, as indicated by $50 \mu \mathrm{M}$ luminol; (b) timedependent $\mathrm{O}_{2}{ }^{\bullet-}$ decay kinetics using $\mathrm{nTiO}_{2}$ as a model in darkness after irradiation, as indicated by $50 \mu \mathrm{M}$ luminol; (c) ${ }^{\circ} \mathrm{OH}$ generation kinetics indicated by the capture of $20 \mu \mathrm{M}$ Phth, $50 \mu \mathrm{M} \mathrm{H}_{2} \mathrm{O}_{2}$ and $0.1 \mathrm{mM} \mathrm{K}_{5} \mathrm{Cu}\left(\mathrm{HIO}_{6}\right)_{2} ;(\mathrm{d}) \mathrm{H}_{2} \mathrm{O}_{2}$ generation kinetics, as indicated by $50 \mu \mathrm{M}$ luminol and $0.1 \mathrm{mM} \mathrm{K}_{3} \mathrm{Fe}(\mathrm{CN})_{6}$. Light intensity: $1.1 \mathrm{~mW} / \mathrm{cm}^{2}$, Room temperature: $22^{\circ} \mathrm{C}$, Initial pH: 7.0 , and an initial nanoparticle concentration: $100 \mathrm{mg} / \mathrm{L}$.

$\mathrm{H}_{2} \mathrm{O}_{2}$ and $0.1 \mathrm{mM} \mathrm{K} \mathrm{K}_{5} \mathrm{Cu}\left(\mathrm{HIO}_{6}\right)_{2}$ in an alkaline medium $(1 \mathrm{M}$ $\left.\mathrm{Na}_{2} \mathrm{CO}_{3}\right){ }^{16}$

For $\mathrm{H}_{2} \mathrm{O}_{2}$, metal oxide particle suspensions were photoexcited and then kept in darkness for $30 \mathrm{~min}$ to eliminate shortlived ROS. ${ }^{27}$ The suspensions were then mixed with $50 \mu \mathrm{M}$ luminol and $0.1 \mathrm{mM} \mathrm{K}_{3} \mathrm{Fe}(\mathrm{CN})_{6}$ prior to their addition to the detection cell for $\mathrm{CL}$ signal detection. ${ }^{16}$

Assessment of Acute Toxicity. The acute toxicity tests with the bioluminescent marine bacteria $P$. phosphoreum (lyophilized, stored at $-20{ }^{\circ} \mathrm{C}$ ) followed the methodology proposed by GB/T15441-1995..$^{28}$ All chemicals were diluted and tested in $3 \% \mathrm{NaCl}$ (isotonic solution for $P$. phosphoreum 502) and the $\mathrm{pH}$ values were adjusted to 7.0. The particles were left in contact with $P$. phosphoreum 502 for 15 min before luminescence measurement. ${ }^{29}$ To study whether the NP toxicity only involved ROS-induced damage, the concentration of the metal oxide NPs was selected to exclude toxicity induced by the release of metal ions. Two different exposure procedures involving the metal oxides and bacteria were performed (Figure S3): (1) Traditional toxicity test: $20 \mathrm{~mL}$ of dispersed NP suspensions and $500 \mu \mathrm{L}$ of $P$. phosphoreum 502 were mixed, allowed to rest for $15 \mathrm{~min}$, and then exposed to UV light. At different exposure times, the suspension was collected and injected into the detection cell, and the luminescence intensity was measured. (2) Postillumination toxicity test: $20 \mathrm{~mL}$ of metal oxide particle suspensions were illuminated by UV light for different periods of time. The light source was then turned off. After $10 \mathrm{~s}, 2 \mathrm{~mL}$ of the suspension was sampled and mixed with $50 \mu \mathrm{L}$ of $P$. phosphoreum 502 suspension and allowed to rest for $15 \mathrm{~min}$. The mixture was then injected into the luminescence detection cell, and its luminescence intensity was measured. These tests determined toxicity based on the inhibition of luminescence emitted by the bacteria $P$. phosphoreum 502. The inhibition of bacterial luminescence (INH\%) caused by the addition of metal oxide nanoparticles was calculated as follows: ${ }^{30}$

$$
\mathrm{INH} \%=100-\frac{\mathrm{IT}_{15}}{\mathrm{KF} \times \mathrm{IT}_{0}} \times 100, \quad \text { with } \mathrm{KF}=\frac{\mathrm{IC}_{15}}{\mathrm{IC}_{0}}
$$

Usually, KF (correction factor) characterizes the natural luminescence loss of the control (i.e., bacterial suspension in $3 \% \mathrm{NaCl}$ ) because of the sample's color or turbidity. $\mathrm{IC}_{0}$ and $\mathrm{IT}_{0}$ are the maximum values of luminescence after addition of $50 \mu \mathrm{L}$ of the test bacteria to $2 \mathrm{~mL}$ of the control or test sample, respectively; $\mathrm{IC}_{15}$ and $\mathrm{IT}_{15}$ are the corresponding values after 15 min. In our experiment, the value of KF was set to 1 because of the low concentration of the metal oxide NPs.

Furthermore, the toxic effect was also evaluated through bacterial mortality by plate colony-counting method as described in ref 31 with some modifications: P. phosphoreum 502 was resuscitated and cultured $12 \mathrm{~h}\left(20^{\circ} \mathrm{C}, 100 \mathrm{r}\right)$ in the medium with the following composition $\left(\mathrm{L}^{-1}\right): 30 \mathrm{~g}$ of $\mathrm{NaCl}$, $12.59 \mathrm{~g}$ of $\mathrm{Na}_{2} \mathrm{HPO}_{4} \cdot 12 \mathrm{H}_{2} \mathrm{O}, 1 \mathrm{~g}$ of $\mathrm{KH}_{2} \mathrm{PO}_{4}, 5 \mathrm{~g}$ of yeast extract, $5 \mathrm{~g}$ of tryptone, and $3 \mathrm{~g}$ of glycerol, $\mathrm{pH}$ 7. Then two different exposure procedures were used: (1) $5 \mathrm{~mL}$ of metal oxide particles was mixed with $50 \mu \mathrm{L}$ of precultured $P$. phosphoreum bacteria suspension at a cell dentisity of approximately $2.0 \times 10^{4}$ colony-forming units $(\mathrm{CFU}) / \mathrm{mL}$ and then expored to UV illumination. At different exposure times, $100 \mu \mathrm{L}$ of mixture was sampled and plated onto agar plates and incubated for $48 \mathrm{~h}$ at $22{ }^{\circ} \mathrm{C}$; (2) $5 \mathrm{~mL}$ of postillumination metal oxide particles was sampled within $10 \mathrm{~s}$, and added into $50 \mu \mathrm{L}$ of precultured $P$. phosphoreum bacteria suspension at a cell density of approximately $2.0 \times 10^{4}$ colonyforming units $(\mathrm{CFU}) / \mathrm{mL}$. After a contact time of $15 \mathrm{~min}, 100$ $\mu \mathrm{L}$ of mixture was plated onto agar plates and incubated for 48 $\mathrm{h}$ at $22{ }^{\circ} \mathrm{C}$. The total number of viable bacterial colonies was counted, and the number of dead bacteria was obtained by subtracting the number of colonies on the sample plate from that on a control plate (no particle exposure) incubated under the same conditions. The bacterial mortality was calculated by dividing the number of dead bacteria by the number of the control bacteria.

Measurement of Ion Release. Metal ion release from the nanoparticle suspensions under UV irradiation was measured using the inductively coupled plasma mass spectrometry (ICPMS) method according to the protocol described in previous studies. $^{22,32}$ The particle suspension was sampled and filtered at 
different illumination times. Control experiments were performed in the dark to detect the background metal ion release from particles without UV irradiation, and the background concentration was subtracted from the concentrations of released ions under UV illumination. Concentrations of metal ions in these samples were quantified using ICP-MS (Agilent 7500, USA).

\section{RESULTS AND DISCUSSION}

Analysis of ROS Generation in Photoexcited Metal Oxide Partcle Suspensions. Figure la shows the change of the CL intensity of particle suspensions as a function of UV irradiation time. According to previous reports, ${ }^{16,33} \mathrm{CL}$ in this measurement is related to the production of $\mathrm{O}_{2}{ }^{--}$on the surface of metal oxides illuminated by UV light. All nanoparticles including $\mathrm{nTiO}_{2}, \mathrm{nZnO}, \mathrm{nV}_{2} \mathrm{O}_{5}, \mathrm{nCeO}_{2}, \mathrm{nFe}_{2} \mathrm{O}_{3}$, and $\mathrm{nAl}_{2} \mathrm{O}_{3}$ generate $\mathrm{O}_{2}^{\bullet-}$, and the $\mathrm{O}_{2}{ }^{\bullet-}$ production initially increased sharply and continued to increase until it eventually plateaued. Within $200 \mathrm{~s}$ of illumination, $\mathrm{nTiO}_{2}$ had the highest rate of $\mathrm{O}_{2}{ }^{\bullet-}$ generation, followed by $\mathrm{nZnO}, \mathrm{nFe}_{2} \mathrm{O}_{3}, \mathrm{nV}_{2} \mathrm{O}_{5}$, $\mathrm{nCeO}_{2}$, and $\mathrm{nAl}_{2} \mathrm{O}_{3}$. Afterward, the formation of $\mathrm{O}_{2}{ }^{\bullet-}$ plateaued for all oxides except $\mathrm{nZnO}$ and $\mathrm{nV}_{2} \mathrm{O}_{5}$, which displayed increasing $\mathrm{O}_{2}{ }^{\bullet-}$ formation with longer illumination. The $\mathrm{O}_{2}{ }^{--}$generation rate of $\mathrm{nZnO}$ was much higher than $\mathrm{nV}_{2} \mathrm{O}_{5}$ for $20 \mathrm{~min}$ of irradiation, after which time they became identical. It is noteworthy that the formation of $\mathrm{O}_{2}{ }^{\bullet-}$ with $\mathrm{nAl}_{2} \mathrm{O}_{3}$ was detected despite its low production, indicating the higher sensitivity of the CFCL method than the conventional method. For bulk materials, only $\mathrm{bTiO}_{2}$ and $\mathrm{bZnO}$ produced very small amounts of $\mathrm{O}_{2}{ }^{\bullet-}$. The generation rate for $\mathrm{bTiO}_{2}$ was a little faster than that for $\mathrm{bZnO}$, and the formation of $\mathrm{O}_{2}{ }^{\bullet-}$ plateaued after 700s. The other bulk counterparts did not produce measurable amount of $\mathrm{O}_{2}{ }^{\bullet-}$. In the absence of particles or under dark conditions, no CL signals were detected for any of the particle suspensions.

The concentration of $\mathrm{O}_{2}^{\bullet-}$ was quantified according to the $\mathrm{CL}$ intensity. ${ }^{25}$ Figure 1a presents kinetics data of the various metal oxide nanoparticles. For the same mass concentration and irradiation time, the average concentration of $\mathrm{O}_{2}{ }^{\bullet-}$ followed the order $\mathrm{nTiO}_{2}>\mathrm{nZnO}>\mathrm{nV}_{2} \mathrm{O}_{5}>\mathrm{nFe}_{2} \mathrm{O}_{3}>$ $\mathrm{nCeO}_{2}>\mathrm{nAl}_{2} \mathrm{O}_{3}$ and $\mathrm{bTiO}_{2}>\mathrm{bZnO}$ (Figure S4) after the $\mathrm{O}_{2}{ }^{\bullet-}$ formation rate plateaued. $\mathrm{nTiO}_{2}$ generated the most $\mathrm{O}_{2}{ }^{\bullet-}$, approximately 2 -fold and 6-fold more than $\mathrm{nZnO}$ and $\mathrm{nFe}_{2} \mathrm{O}_{3}$, respectively. There was no significant difference between $\mathrm{nZnO}$ and $\mathrm{nV}_{2} \mathrm{O}_{5}$ for $\mathrm{O}_{2}{ }^{\bullet-}$ generation. $\mathrm{nCeO}_{2}$ and $\mathrm{nAl}_{2} \mathrm{O}_{3}$ generated relatively low concentrations of $\mathrm{O}_{2}{ }^{\bullet-}$ (ca. several nanomolar), but they were still equal to or a little higher than those of $\mathrm{bTiO}_{2}$ and bZnO. The maximum $\mathrm{O}_{2}{ }^{\bullet-}$ concentration was about 180 $\mathrm{nM}$, which is lower than the reported value. ${ }^{22}$ This is probably due to the following two reasons: First, in our measurement the illumination duration of the NPs was only $30 \mathrm{~min}$, whereas in the previous study it was $48 \mathrm{~h}$. Second, as described in the Experimental section, in the CFCL measurement the photoilluminated nanoparticles were mixed with the $C L$ probe outside the photoreactor. Therefore, the $\mathrm{O}_{2}{ }^{\bullet-}$ radicals with short lifetimes had decayed before they reached the detection cell, and only those with long lifetimes were captured. However, in conventional fluorescence or absorbance measurements, the probes are mixed with the nanoparticles in the photoreactor, and consequently all the radicals are captured.

Figure $1 \mathrm{c}$ shows that ${ }^{\circ} \mathrm{OH}$ was generated only in the $\mathrm{nTiO}_{2}$, $\mathrm{nZnO}$ and $\mathrm{bTiO}_{2}, \mathrm{bZnO}$ suspensions under $\mathrm{UV}$ irradiation, and - $\mathrm{OH}$ generation of nanoparticles was much higher than that for their bulk counterparts. Between the two materials, the generation rate of ${ }^{\circ} \mathrm{OH}$ in $\mathrm{nZnO}$ was approximately 3-fold more than $\mathrm{nTiO}_{2}$. Similarly, the generation of ${ }^{\bullet} \mathrm{OH}$ in $\mathrm{bZnO}$ was also faster than $\mathrm{bTiO}_{2}$. In additional, ${ }^{\circ} \mathrm{OH}$ maximum generation concentration was about $150 \mathrm{nM}$, which was also lower than the reported. ${ }^{22}$ This is probably again due to the large difference in illumination duration between the two measurements, as well as the type of $\mathrm{nTiO}_{2}$ used.

Figure 1d shows the $\mathrm{H}_{2} \mathrm{O}_{2}$ formation kinetics of different NPs. $\mathrm{nTiO}_{2}$ generated the largest amount of $\mathrm{H}_{2} \mathrm{O}_{2}$, which is approximately 10 -fold larger than that generated by $\mathrm{nZnO}$, whereas none of the other types of NPs and bulk materials produced measurable amounts of $\mathrm{H}_{2} \mathrm{O}_{2}$.

Analysis of the Energy Band Structures of the Metal Oxide NPs. The generation of a specific type of ROS (e.g., $\mathrm{O}_{2}{ }^{--}$or $\left.{ }^{\bullet} \mathrm{OH}\right)$ in the $\mathrm{NP}$ suspensions under UV illumination can be qualitatively predicted on the basis of the electronic structure and redox potentials $\left(E_{\mathrm{H}}\right)$ of the nanoparticles. Table S2 lists the literature values of the band gap $\left(E_{\mathrm{g}}\right)$, the valence band $\left(E_{\mathrm{v}}\right)$, and the conduction band $\left(E_{\mathrm{c}}\right)$ of the six types of pristine metal oxide NPs used in this work. ${ }^{34,35}$ Note that the band edge energies are not entirely reliable for aqueous environments because the space charge layer and the Helmholtz layer are present at the interface between the nanoparticle and the solution. ${ }^{36}$ The relevant $E_{\mathrm{c}}$ and $E_{\mathrm{v}}$ levels, which were calculated by the Nernst relation, under neutral conditions are shown in Table S3. ${ }^{37}$ In general, ROS can be generated using the incident photon energy and interfacial electron $\left(\mathrm{e}_{\mathrm{cb}}{ }^{-}\right)$/hole $\left(\mathrm{h}_{\mathrm{vb}}{ }^{+}\right)$pairs. Only metal oxide NPs with $E_{\mathrm{g}}$ values less than the photoexcitation energy (approximately 3.4 $\mathrm{eV}$ for $365 \mathrm{~nm}$ UV light) permit photoexcitation from $E_{\mathrm{v}}$ to $E_{\mathrm{c}}$ with concomitant hole formation in the valence band. The photoexcited electrons and holes then migrate on the NP surface and participate in redox reactions with the adsorbed electron acceptor $\left(\mathrm{O}_{2}\right)$ and donor $\left(\mathrm{H}_{2} \mathrm{O}\right)$ to generate ${ }^{\bullet} \mathrm{OH}$ and $\mathrm{O}_{2}{ }^{\bullet-}$.

Clearly, the reducing power of the conduction band plays an important role in the formation of $\mathrm{O}_{2}{ }^{--}$. The $E_{\mathrm{c}}$ values of $\mathrm{nTiO}_{2}, \mathrm{nZnO}$, and $\mathrm{nCeO}_{2}(-0.36,-0.2$, and -1.77 with respect to $\mathrm{NHE}$, respectively) are lower than the $E_{\mathrm{H}}$ of $\mathrm{O}_{2} /$ $\mathrm{O}_{2}{ }^{\bullet-}(-0.2 \mathrm{eV}) .^{38}$ Thus, the reducting power of the photoexcited electrons in $\mathrm{nTiO}_{2}, \mathrm{nZnO}$ and $\mathrm{nCeO}_{2}$ are sufficient to reduce $\mathrm{O}_{2}$ to $\mathrm{O}_{2}{ }^{\bullet-}$, which agrees with the experimental results shown in Figure 1a. Although the $E_{\mathrm{c}}$ values of $\mathrm{nV}_{2} \mathrm{O}_{5}$ and $\mathrm{nFe}_{2} \mathrm{O}_{3}(0.17$ and $0.37 \mathrm{eV}$, respectively) are higher than the $E_{\mathrm{H}}$ of $\mathrm{O}_{2} / \mathrm{O}_{2}{ }^{\bullet-}$, a considerable amount of $\mathrm{O}_{2}^{\bullet-}$ was produced on these two nanoparticles. For $\mathrm{nV}_{2} \mathrm{O}_{5}$, this occurred probably because UV photons induced the formation of surface defects (mainly $\mathrm{V}^{4+}$ ), which have been proposed to play a vital role in electron transfer for $\mathrm{O}_{2}{ }^{\bullet-}$ generation. ${ }^{39}$ As an $\mathrm{N}$-type semiconductor, ${ }^{40} \mathrm{nFe}_{2} \mathrm{O}_{3}$ may have an upward-bending conduction band owing to the accumulation of positive charge within the space charge region of the electrostatic double layer. ${ }^{34}$ Thus, the actual $E_{\mathrm{c}}$ could be lower than $-0.2 \mathrm{eV}$, and would allow electron transfer to the adsorbed $\mathrm{O}_{2}$ molecules ${ }^{22}$ Notably, conventional understanding precludes photoexcitation of $\mathrm{nAl}_{2} \mathrm{O}_{3}$ owing to its high $E_{\mathrm{g}}$ value. However, $\mathrm{O}_{2}{ }^{\bullet-}$ generation was detected with the $\mathrm{nAl}_{2} \mathrm{O}_{3}$ suspension, as shown in Figure 1a. The $\mathrm{O}_{2}{ }^{\bullet-}$ production in this case was likely caused by electrons at the surface states of $\mathrm{nAl}_{2} \mathrm{O}_{3}$ being excited from the valence band. ${ }^{41}$

The redox couple of $\mathrm{H}_{2} \mathrm{O} /{ }^{\bullet} \mathrm{OH}$ is $2.39 \mathrm{eV}$ with respect to NHE (Table S4), ${ }^{42}$ which is lower than the $E_{\mathrm{v}}$ values of $\mathrm{nTiO}_{2}$, 

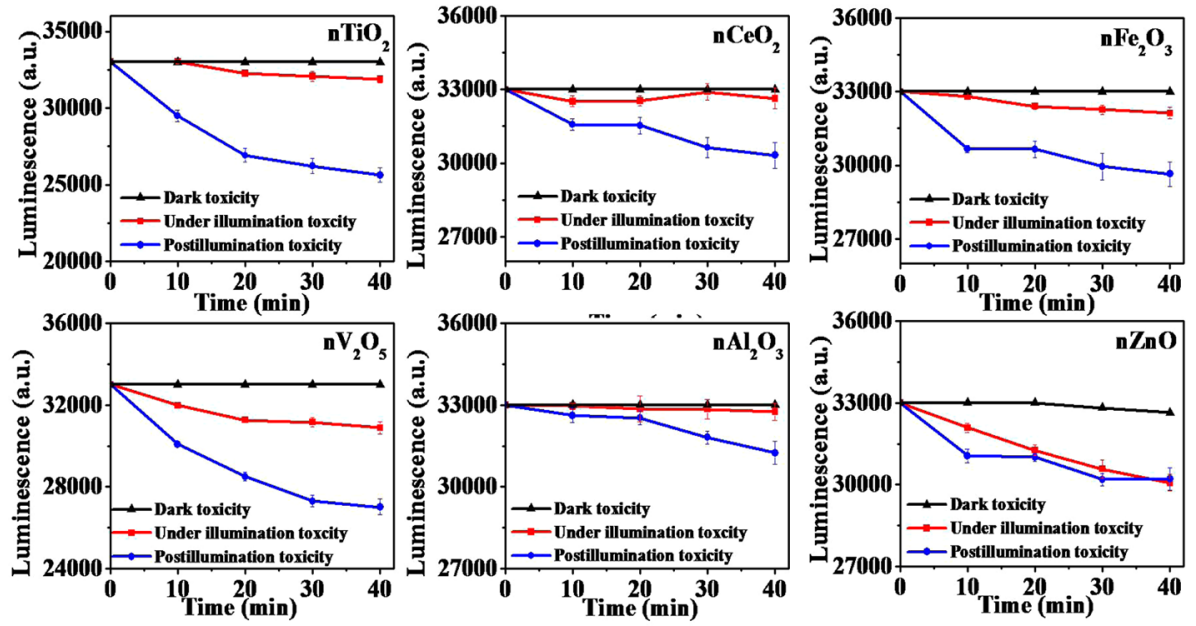

Figure 2. Toxicity of different NPs with (a) P. phosphoreum 502 exposed to NPs in the dark; (b) P. phosphoreum 502 exposed to metal oxides NPs under UV illumination; (c) P. phosphoreum 502 exposed to the post-UV illumination NPs. $\mathrm{nTiO}_{2}: 10 \mathrm{mg} / \mathrm{L} ; \mathrm{nCeO}: 100 \mathrm{mg} / \mathrm{L} ; \mathrm{nFe} \mathrm{O}_{3}: 50 \mathrm{mg} / \mathrm{L}$, $\mathrm{nV}_{2} \mathrm{O}_{5}: 20 \mathrm{mg} / \mathrm{L} ; \mathrm{nAl}_{2} \mathrm{O}_{3}: 100 \mathrm{mg} / \mathrm{L}$, and $\mathrm{nZnO}: 3 \mathrm{mg} / \mathrm{L}$.
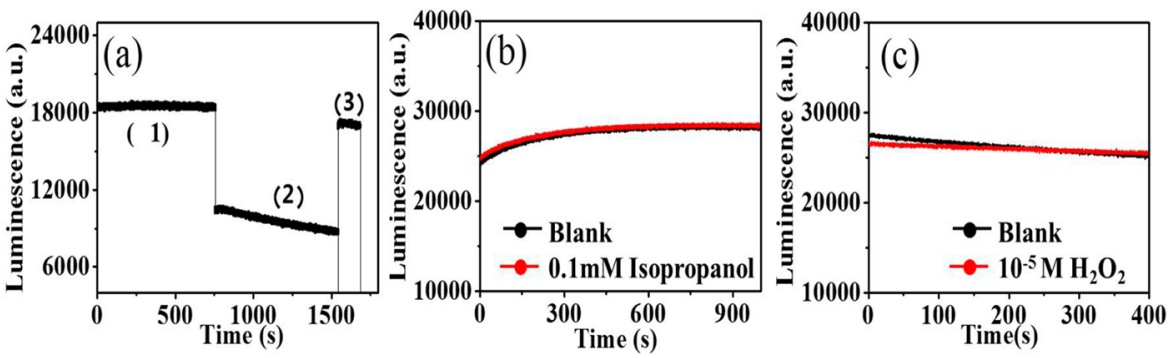

Figure 3. Effect of radical scavenging on the $\mathrm{CL}$ intensity of $P$. phosphoreum 502 when exposed the $100 \mathrm{mg} / \mathrm{L}$ nTiO $\mathrm{O}_{2}$ suspensions. (a) $\mathrm{O}_{2}{ }^{\bullet-}$ scavenger, SOD (1) P. phosphoreum 502 exposed to $\mathrm{nTiO}_{2}$ in the dark, (2) P. phosphoreum 502 exposed to post-UV irradiation $\mathrm{nTiO} 2,(3) P$. phosphoreum 502 exposed to post-UV irradiation $\mathrm{nTiO}_{2}$ with $5 \mathrm{U} / \mathrm{mL} \mathrm{SOD;} \mathrm{(b)}{ }^{\bullet} \mathrm{OH}$ scavenger, Isopropanol; (c) $\mathrm{H}_{2} \mathrm{O}_{2}$.

$\mathrm{nZnO}, \mathrm{nFe}_{2} \mathrm{O}_{3}$, and $\mathrm{nV}_{2} \mathrm{O}_{5}(2.84,3.00,2.57$, and $2.97 \mathrm{eV}$, respectively, as shown in Table S3). Theoretically, the holes of these NPs can oxidize $\mathrm{H}_{2} \mathrm{O}$ to generate ${ }^{\bullet} \mathrm{OH}$, which partially agrees with the experimental observations shown in Figure 1c. The ${ }^{\bullet} \mathrm{OH}$ was not detected in the $\mathrm{nFe}_{2} \mathrm{O}_{3}$ suspensions, probably because the difference was not substantial between the $E_{\mathrm{v}}$ of $\mathrm{nFe}_{2} \mathrm{O}_{3}$ and the $E_{\mathrm{H}}$ of ${ }^{\bullet} \mathrm{OH}$ generation (data not shown). ${ }^{22} \mathrm{UV}$ light cannot excite $\mathrm{nAl}_{2} \mathrm{O}_{3}$ owing to its high $E_{\mathrm{g}}$ value. Consequently, no ${ }^{\circ} \mathrm{OH}$ was detected in the $\mathrm{nAl}_{2} \mathrm{O}_{3}$ suspensions, which agrees with our experimental observations (data not shown).

Generally, $\mathrm{H}_{2} \mathrm{O}_{2}$ is understood to be a self-disproportionation product following equilibration with initially generated species (e.g., $\mathrm{O}_{2}{ }^{--}$), with its formation being limited by the production of such species. In this way, $\mathrm{H}_{2} \mathrm{O}_{2}$ was observed only in the $\mathrm{nTiO}_{2}$ and $\mathrm{nZnO}$ suspensions (Figure 1d), presumably because these two metal oxide NPs can generate a relatively large amount of ROS, especially $\mathrm{O}_{2}{ }^{\bullet-}$.

ROS-Mediated Toxicity of the Metal Oxide Particles to P. phosphoreum 502 after Photoillumination. To determine the acute phototoxicity of the metal oxide particles induced by ROS, we performed a luminous bacteria inhibition assay with $P$. phosphoreum 502. Other factors that may potentially affect the toxicity of metal oxide particles, such as ion release, were first excluded. Then, the no observed effect concentration (NOEC) of the NPs under dark conditions was measured. ${ }^{43}$ NOEC is defined as the highest tested concentration that did not inhibit luminescence of $P$. phosphoreum 502. ${ }^{30}$ The dose-effect curves of the test NPs are shown in Figure S5. The $\mathrm{nTiO}_{2}$ suspension was not acutely toxic, even at concentrations of several hundred milligrams per liter. In contrast, the $\mathrm{nZnO}$ suspension was very toxic to $P$. phosphoreum 502, and the NOEC of $\mathrm{nZnO}$ for $P$. phosphoreum 502 was approximately $3 \mathrm{mg} / \mathrm{L}$. As seen in Figure S5, the NOECs were determined to be $100 \mathrm{mg} / \mathrm{L}$ for $\mathrm{nAl}_{2} \mathrm{O}_{3}, 100 \mathrm{mg} /$ $\mathrm{L}$ for $\mathrm{nCeO}_{2}, 50 \mathrm{mg} / \mathrm{L}$ for $\mathrm{nFe}_{2} \mathrm{O}_{3}, 20 \mathrm{mg} / \mathrm{L}$ for $\mathrm{nV}_{2} \mathrm{O}_{5}$ and 3 $\mathrm{mg} / \mathrm{L}$ for $\mathrm{nZnO}$. Considering that the ROS generation from $\mathrm{nTiO}_{2}$ was far more than the other NPs, $10 \mathrm{mg} / \mathrm{L}$ of $\mathrm{nTiO}_{2}$ was selected as its NOEC.

Under the above NOEC concentration obtained in the dark, the toxicity tests of the six different metal oxide NPs and their bulk counterparts with photoillumination were performed using two separate experimental procedures, namely the traditional test and postillumination test (Figure S3). Our initial purpose was to investigate the role and contribution of each type of ROS on the toxicity. The traditional toxicity test was used to evaluate the effect of the total ROS, whereas the postillumination toxicity test was used to investigate the contribution of the long-lived superoxide radical on the toxicity. As shown in Figure 2, when the luminescent bacteria were exposed to the metal oxide NPs under illumination, the luminescence did not change significantly by comparison with the signal in the dark, except for $\mathrm{nZnO}$. The results may have occurred because the bacteria became adsorbed on the metal oxide NPs surface, which affected their surface properties and inhibited ROS generation (Figure S6). However, when P. phosphoreum 502 
was exposed to the postillumination metal oxide NPs under dark conditions, the luminescence inhibition efficiency decreased significantly (Figure 2). Moreover, the average luminescence inhibition efficiency of the metal oxide NPs for $P$. phosphoreum at the same mass concentrations followed the order $\mathrm{nTiO}_{2}>\mathrm{nZnO}>\mathrm{nV}_{2} \mathrm{O}_{5}>\mathrm{nFe}_{2} \mathrm{O}_{3}>\mathrm{nCeO}_{2}>\mathrm{nAl}_{2} \mathrm{O}_{3}$. Note that this order corresponds to the order for the amount of $\mathrm{O}_{2}{ }^{\bullet-}$ species generated on various NPs (Figure la). Therefore, we speculate that the long-lived $\mathrm{O}_{2}^{\bullet-}$ is primarily responsible for the postillumination toxic effect. For the bulk materials, in either the traditional test or postillumination test no toxic effect was observed, most likely due to their low $\mathrm{O}_{2}^{\bullet-}$ production (data not shown). To further investigate the role(s) of longlived $\mathrm{O}_{2}{ }^{--}$on the postillumination toxic effect of $P$. phosphoreum 502, ROS radical scavengers were added to the postillumination metal oxide NPs. The luminescence of $P$. phosphoreum 502 recovered dramatically following the addition of superoxide dismutase (SOD), an $\mathrm{O}_{2}{ }^{\bullet-}$ scavenger $^{44}$ (Figure $3 \mathrm{a})$, whereas isopropanol $\left({ }^{\bullet} \mathrm{OH} \text { scavenger }\right)^{21}$ and $10^{-5} \mathrm{M} \mathrm{H}_{2} \mathrm{O}_{2}$ had no effect on the intensity (Figure $3 \mathrm{~b}, \mathrm{c}$ ). As shown in Figure 1c, $\mathrm{H}_{2} \mathrm{O}_{2}$ generation was in the micromolar range in our experiments. Therefore, the results confirmed that the main ROS involved in toxicity of $P$. phosphoreum 502 was the longlived $\mathrm{O}_{2}{ }^{\bullet-}$ species and not ${ }^{\bullet} \mathrm{OH}$ or $\mathrm{H}_{2} \mathrm{O}_{2}$. To the best of our knowledge, this is the first report concerning the postillumination toxic effect of metal oxide NPs induced by long-lived $\mathrm{O}_{2}{ }^{\bullet-}$.

In order to further confirm the postillumination toxic effect of metal oxide NPs, plate colony counting experiments were also performed at the NOEC NPs concentrations. The results showed that $\mathrm{nAl}_{2} \mathrm{O}_{3}$ and $\mathrm{nFe}_{2} \mathrm{O}_{3}, \mathrm{nCeO}_{2}, \mathrm{nTiO}_{2}, \mathrm{nV}_{2} \mathrm{O}_{5}$ and nZnO obviously harm P. phosphoreum 502 (data not shown). Furthermore, the relationship between bacterial luminescence inhibition and mortality was investigated quantitatively at three different $\mathrm{nTiO}_{2}$ concentrations. In Figure 4, with the prolonged UV illumination on the metal oxides, both the luminescence

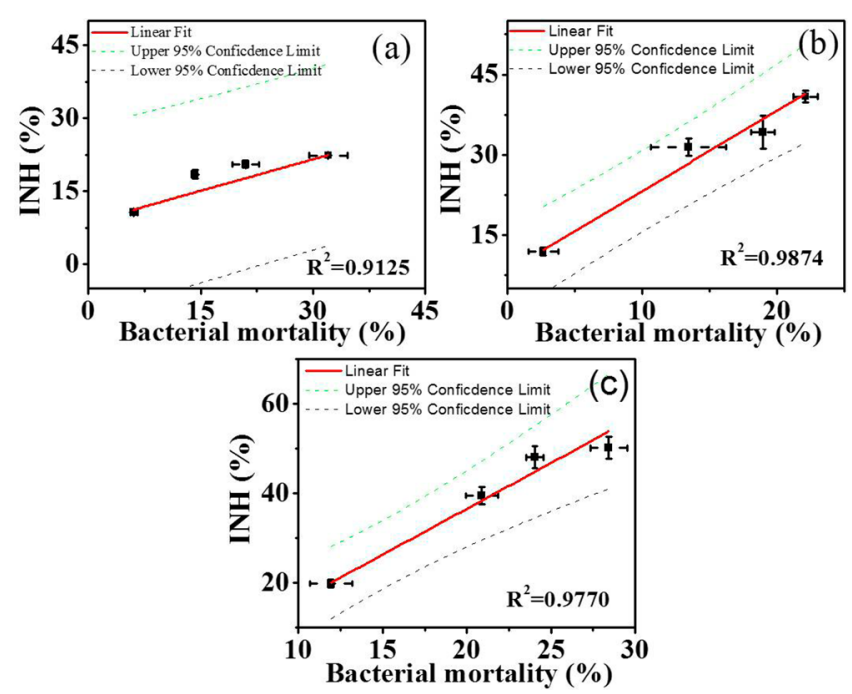

Figure 4. Linear relationship between the bacterial mortality and inhibition of bacterial luminescence (INH\%) exposed to the post-UV illumination $\mathrm{nTiO}_{2}$ suspensions with the $95 \%$ confidence limits shown to indicate the curve fit uncertainty in which the $\mathrm{nTiO}_{2}$ suspensions were illuminated $10,20,30$, and 40 min by UV light, respectively, and the concentration of $\mathrm{nTiO}_{2}$ was (a) $10 \mathrm{mg} / \mathrm{L}$; (b) $60 \mathrm{mg} / \mathrm{L}$; (c) 80 $\mathrm{mg} / \mathrm{L}$. inhibition rate (INH\%) and the bacterial mortality increased, and the correlation between the two was statistically significant, with a correlation coefficient $R^{2}>0.90$. These results suggest that the bacterial luminescence analysis can be used to evaluate the possible toxic effect involving the ROS generation with the advantages of rapidity and simplicity. In additional, the bulk materials did not show any postillumination toxic effect in the plate colony counting tests. Therefore, particle size also has significant impact on the postillumination toxic effect of metal oxides particles toward P. phosphoreum 502, which is consistent with many other reports. ${ }^{22,45}$

Although other factors such as ion release were excluded by using the NOEC concentrations of the metal oxides NPs under dark conditions, the ion release effect in the suspensions of different metal oxide NPs under the 40 min illumination was still monitored. It was found that only $\mathrm{nZnO}$ released ions. In $\mathrm{nZnO}$ suspension (initial concentration $3 \mathrm{mg} / \mathrm{L}$ ), the equilibrium concentration of the released $\mathrm{Zn}^{2+}$ was about $78.5 \mu \mathrm{g} / \mathrm{L}$. The toxic effect of free $\mathrm{Zn}^{2+}$ ions was then analyzed by performing the inhibition of bacterial luminescence assay with various concentrations of $\mathrm{ZnSO}_{4}$. A modest luminescence inhibition toward P. phosphoreum 502 was observed (Figure S7), which might explain why $\mathrm{nZnO}$ exhibited some inhibition toward P. phosphoreum 502 even in the dark (Figure 1).

Relationship between the Toxicity Potency of NPs and Superoxide Generation. Oxidative stress generated from ROS is usually the governing mechanism for the antibacterial activity of engineered NPs, especially in the presence of UV illumination. ${ }^{46}$ To further investigate the roles of long-lived $\mathrm{O}_{2}{ }^{\bullet-}$ radical in the postillumination toxic effect, the relationship between the $\mathrm{O}_{2}{ }^{--}$generation from metal oxide NPs and the inhibition of bacterial luminescence was studied. First, $\mathrm{nTiO}_{2}$ suspensions with various concentrations were irradiated, and the $\mathrm{O}_{2}{ }^{\bullet-}$ radical was then detected using the CFCL methods (Figure 5a). In parallel, the INH\% of the postirradiation suspensions with the luminescence bacteria were detected (Figure 5b). As seen, the measured signals increased as the $\mathrm{nTiO}_{2}$ concentration increased, and the rate of increase was very similar between the CL intensity and INH\%. The $\mathrm{O}_{2}{ }^{\bullet-}$ generation of the six different metal oxide NPs (i.e., $\mathrm{nTiO}_{2}, \mathrm{nZnO} \mathrm{nV}_{2} \mathrm{O}_{5}, \mathrm{nCeO}_{2}, \mathrm{nFe}_{2} \mathrm{O}_{3}$, and $\mathrm{nAl}_{2} \mathrm{O}_{3}$ ) and their postillumination toxic effect were also investigated. Figure $5 \mathrm{~d}$ shows the INH\% to follow the order $\mathrm{nTiO}_{2}>\mathrm{nV}_{2} \mathrm{O}_{5}>\mathrm{nZnO}>$ $\mathrm{nFe}_{2} \mathrm{O}_{3}>\mathrm{nCeO}_{2}>\mathrm{nAl}_{2} \mathrm{O}_{3}$, which is consistent with the order of $\mathrm{O}_{2}{ }^{\bullet-}$ generation. But the result is different from the order $\mathrm{nTiO}_{2}>\mathrm{nZnO}>\mathrm{nAl}_{2} \mathrm{O}_{3}>\mathrm{nFe}_{2} \mathrm{O}_{3}>\mathrm{nCeO}_{2}$ in the previous report. $^{22}$ The difference may be attributed to the sources and concentrations of NPs used in the experiments. More importantly, we investigated the postillumination toxic effect of metal oxide NPs in the dark which is caused only by the long-lived $\mathrm{O}_{2}{ }^{--}$on the NPs. The rate of INH\% increase is similar to the rate of $\mathrm{O}_{2}{ }^{\bullet-}$ generation. Overall, these results indicate that the luminescence inhibition of $P$. phosphoreum 502 was mainly caused by the enhanced generation of long-lived $\mathrm{O}_{2}{ }^{--}$radicals on the metal oxide NPs after UV illumination.

Establishing a quantitative correlation between the $\mathrm{O}_{2}{ }^{--}$ radical generation and the bactericidal effect of postillumination metal oxide NPs would be useful for evaluating and predicting the postillumination toxic potency of nanomaterials. To this end, we determined the $\mathrm{O}_{2}^{\bullet-}$ concentrations at different UV illumination time intervals for various $\mathrm{nTiO}_{2}$ concentrations and different metal oxides NPs and plotted these against the corresponding inhibitions of bacterial luminescence (INH\%) of 

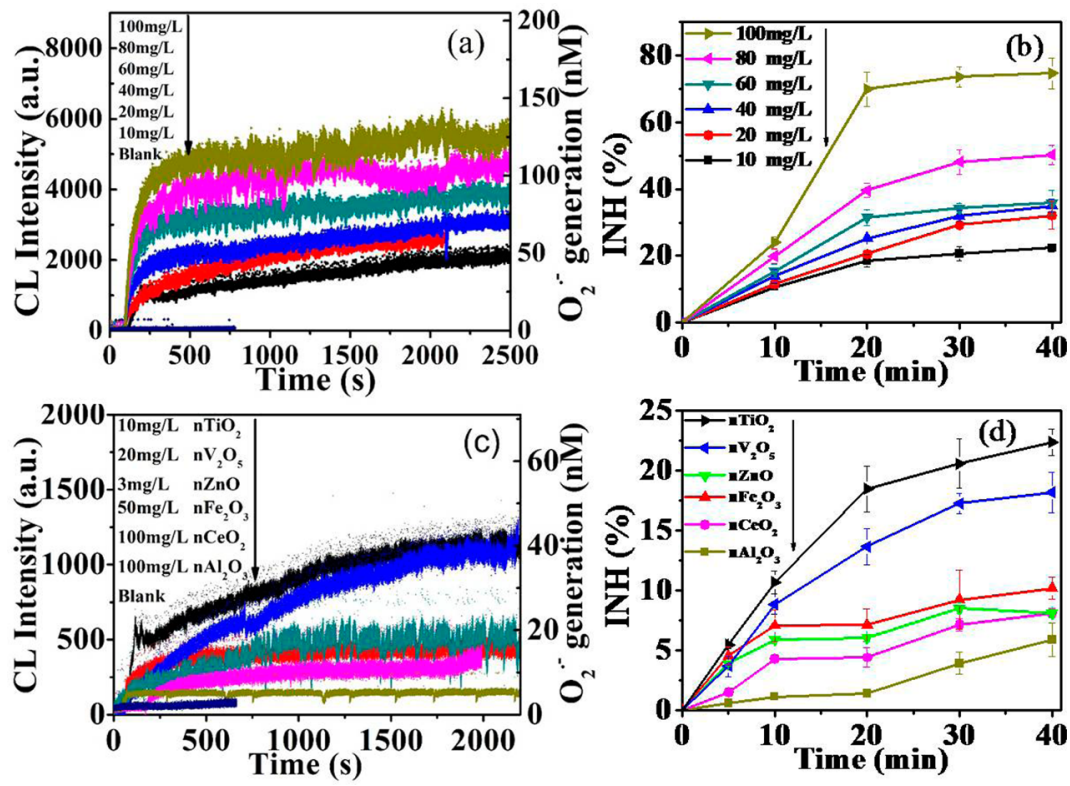

Figure 5. (a) Kinetics of $\mathrm{O}_{2}{ }^{\bullet-}$ generation for the different $\mathrm{nTiO}_{2}$ concentrations with irradiation; (b) inhibition of bacterial luminescence (INH\%) with increasing irradiation time; (c) kinetics of $\mathrm{O}_{2}{ }^{--}$generation with different metal oxide NPs irradiation; (d) INH\% of different post-UV irradiation NPs with increasing irradiation time.

P. phosphoreum 502. These data are shown in Figure 6 and Figures S8 and S9. Evidently, the INH\% increased linearly with
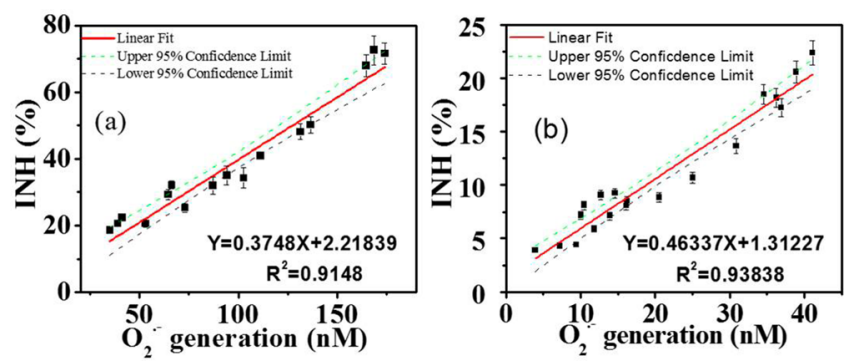

Figure 6. Linear relationship between $\mathrm{INH} \%$ and $\mathrm{O}_{2}{ }^{--}$generation by (a) different concentrations of $\mathrm{TiO}_{2}$ and (b) various NPs, with the $95 \%$ confidence limits shown to indicate the curve fit uncertainty.

the $\mathrm{O}_{2}{ }^{\bullet-}$ concentration, with a correlation coefficient $R^{2}>0.90$. We performed a linear regression of the experimental data in Figure 6 using the linear fit equation

$$
Y=A X+B
$$

where $Y$ and $X$ are the INH\% and $\mathrm{O}_{2}{ }^{\bullet-}$ generation, respectively. The fit parameter $B$ was determined to be 2.21839 and 1.31227 , respectively, for the two curves, which are within the intervals of $[-0.55544,4.99222]$ and $[0.64999,1.97455]$ with a confidence level of $95 \%$. According to the $t$ test, the $p$ values for parameter $B$ are $7.13 \times 10^{-10}$ and $1.45 \times 10^{-12}$, which are far less than the significance level of 0.05 and indicate that this parameter is significantly different from 0 . Moreover, this result demonstrates that the linear relationship between INH\% and the average concentration of long-lived $\mathrm{O}_{2}{ }^{\bullet-}$ is statistically significant. The combined results in Figures S6 and S7 strongly support the notion that long-lived $\mathrm{O}_{2}{ }^{-\boldsymbol{}}$ in the metal oxide NPs played a major role in the postillumination toxic effect.

\section{ASSOCIATED CONTENT}

\section{Supporting Information}

The Supporting Information is available free of charge on the ACS Publications website at DOI: 10.1021/acs.est.7b00473.

CFCL apparatus for ROS dynamic detection, two different exposure experimental procedures for metal oxides and bacteria, ROS generation in aqueous suspension containing different NPs under UV irradiation, dose-effect curves of different NPs on luminescence bacteria under dark conditions, inhibition of ROS generation by $P$. phosphoreum 502 and the linear relationship between the INH\% and the $\mathrm{O}_{2}{ }^{--}$generation by gradient concentration of $\mathrm{TiO}_{2}$ or different NPs at different irradiation times, tabulated characterization of the metal oxide particles, band edge energy of the six metal oxides, and redox potentials of the aqueous redox couples (PDF)

\section{AUTHOR INFORMATION}

\section{Corresponding Authors}

*Phone: (86) 10-62849338; fax: (86)10-62849685; e-mail: zlx@rcees.ac.cn.

*Phone: (86) 10-62849685; fax: (86)10-62849685; e-mail: LHGuo@rcees.ac.cn.

\section{ORCID}

Lixia Zhao: 0000-0002-2068-4732

Notes

The authors declare no competing financial interest.

\section{ACKNOWLEDGMENTS}

We gratefully acknowledge financial support from the National Key Research and Development Program of China (2016YFA0203102), the Chinese Academy of Sciences (XDB14040100), and the National Natural Science Foundation of China (Nos. 21677152, 21177138, 21321004, 21527901, 91543203, and 21577156). 


\section{REFERENCES}

(1) Wang, Z.; Lee, Y.-H.; Wu, B.; Horst, A.; Kang, Y.; Tang, Y. J.; Chen, D.-R. Anti-microbial activities of aerosolized transition metal oxide nanoparticles. Chemosphere 2010, 80, 525-529.

(2) Dasari, T. P.; Pathakoti, K.; Hwang, H.-M. Determination of the mechanism of photoinduced toxicity of selected metal oxide nanoparticles $\left(\mathrm{ZnO}, \mathrm{CuO}, \mathrm{Co}_{3} \mathrm{O}_{4}\right.$ and $\left.\mathrm{TiO}_{2}\right)$ to E. coli bacteria. $J$. Environ. Sci. 2013, 25, 882-888.

(3) Serpone, N.; Dondi, D.; Albini, A. Inorganic and organic UV filters: Their role and efficacy in sunscreens and suncare products. Inorg. Chim. Acta 2007, 360, 794-802.

(4) Cai, R.; Van, G.; Aw, P.; Itoh, K. Solar-driven self-cleaning coating for a painted surface. C. R. Chim. 2006, 9, 829-835.

(5) Yuranova, T.; Laub, D.; Kiwi, J. Synthesis, activity and characterization of textiles showing self-cleaning activity under daylight irradiation. Catal. Today 2007, 122, 109-117.

(6) Keller, V.; Keller, N.; Ledoux, M. J.; Lett, M.-C. Biological agent inactivation in a flowing air stream by photocatalysis. Chem. Commun. 2005, 23, 2918-2920.

(7) Matsunaga, T.; Tomoda, R.; Nakajima, T.; Wake, H. Photoelectrochemical sterilization of microbial cells by semiconductor powders. FEMS Microbiol. Lett. 1985, 29, 211-214.

(8) Leung, Y. H.; Xu, X.; Ma, A. P.; Liu, F.; Ng, A. M.; Shen, Z.; Gethings, L. A.; Guo, M. Y.; Djurišić, A. B.; Lee, P. K. Toxicity of ZnO and $\mathrm{TiO}_{2}$ to Escherichia coli cells. Sci. Rep. 2016, 6, 35243.

(9) Brunet, L. n.; Lyon, D. Y.; Hotze, E. M.; Alvarez, P. J.; Wiesner, M. R. Comparative photoactivity and antibacterial properties of C60 fullerenes and titanium dioxide nanoparticles. Environ. Sci. Technol. 2009, 43, 4355-4360.

(10) Yadav, H. M.; Kim, J.-S.; Pawar, S. H. Developments in photocatalytic antibacterial activity of nano $\mathrm{TiO}_{2}$ : A review. Korean J. Chem. Eng. 2016, 33, 1989-1998.

(11) Yang, H.; Mei, S.; Zhao, L.; Zhang, Y. Effects of Ultraviolet Irradiation on the Antibacterial Activity of $\mathrm{TiO}_{2}$ Nanotubes. Nanosci. Nanotechnol. Lett. 2016, 8, 498-504.

(12) Jiang, Y.; Zhang, L.; Wen, D.; Ding, Y. Role of physical and chemical interactions in the antibacterial behavior of $\mathrm{ZnO}$ nanoparticles against E. coli. Mater. Sci. Eng., C 2016, 69, 1361-1366.

(13) Baek, Y.-W.; An, Y.-J. Microbial toxicity of metal oxide nanoparticles $\left(\mathrm{CuO}, \mathrm{NiO}, \mathrm{ZnO}\right.$, and $\mathrm{Sb}_{2} \mathrm{O}_{3}$ ) to Escherichia coli, Bacillus subtilis, and Streptococcus aureus. Sci. Total Environ. 2011, 409, 1603-1608.

(14) Heinlaan, M.; Ivask, A.; Blinova, I.; Dubourguier, H.-C.; Kahru, A. Toxicity of nanosized and bulk $\mathrm{ZnO}, \mathrm{CuO}$ and $\mathrm{TiO}_{2}$ to bacteria Vibrio fischeri and crustaceans Daphnia magna and Thamnocephalus platyurus. Chemosphere 2008, 71, 1308-1316.

(15) Djurišić, A. B.; Leung, Y. H.; Ng, A.; Xu, X. Y.; Lee, P. K.; Degger, N. Toxicity of metal oxide nanoparticles: Mechanisms, characterization, and avoiding experimental artefacts. Small 2015, 11, $26-44$.

(16) Wang, D.; Zhao, L.; Guo, L.-H.; Zhang, H. Online detection of reactive oxygen species in ultraviolet (UV)-irradiated nano- $\mathrm{TiO}_{2}$ suspensions by continuous flow chemiluminescence. Anal. Chem. 2014, 86, 10535-10539.

(17) Du, J.; Gebicki, J. M. Proteins are major initial cell targets of hydroxyl free radicals. Int. J. Biochem. Cell Biol. 2004, 36, 2334-2343.

(18) Bakalova, R.; Ohba, H.; Zhelev, Z.; Ishikawa, M.; Baba, Y. Quantum dots as photosensitizers? Nat. Biotechnol. 2004, 22, 13601361.

(19) Wang, S.; Gao, R.; Zhou, F.; Selke, M. Nanomaterials and singlet oxygen photosensitizers: potential applications in photodynamic therapy. J. Mater. Chem. 2004, 14, 487-493.

(20) Fridovich, I. Biological effects of the superoxide radical. Arch. Biochem. Biophys. 1986, 247, 1-11.

(21) Zhang, L.-S.; Wong, K.-H.; Yip, H.-Y.; Hu, C.; Yu, J. C.; Chan, C.-Y.; Wong, P.-K. Effective photocatalytic disinfection of E. coli K-12 using $\mathrm{AgBr}-\mathrm{Ag}-\mathrm{Bi}_{2} \mathrm{WO}_{6}$ nanojunction system irradiated by visible light: the role of diffusing hydroxyl radicals. Environ. Sci. Technol. 2010, 44, 1392-1398.
(22) Li, Y.; Zhang, W.; Niu, J.; Chen, Y. Mechanism of photogenerated reactive oxygen species and correlation with the antibacterial properties of engineered metal oxide nanoparticles. ACS Nano 2012, 6, 5164-5173.

(23) Zhang, W.; Li, Y.; Niu, J.; Chen, Y. Photogeneration of reactive oxygen species on uncoated silver, gold, nickel, and silicon nanoparticles and their antibacterial effects. Langmuir 2013, 29, 4647-4651.

(24) Sawai, J.; Kojima, H.; Igarashi, H.; Hashimoto, A.; Shoji, S.; Sawaki, T.; Hakoda, A.; Kawada, E.; Kokugan, T.; Shimizu, M. Antibacterial characteristics of magnesium oxide powder. World J. Microbiol. Biotechnol. 2000, 16, 187-194.

(25) Dabin, W.; Lixia, Z.; Lianghong, G.; Hui, Z.; Bin, W.; Yu, Y. Online Quantification of $\mathrm{O}_{2}{ }^{--}$(center dot-) and $\mathrm{H}_{2} \mathrm{O}_{2}$ and Their Formation Kinetics in Ultraviolet (UV)-Irradiated $\mathrm{Nano}^{-\mathrm{TiO}_{2}}$ Suspensions by Continuous Flow Chemiluminescence. Acta Chim. Sinica 2015, 73, 388-394.

(26) Miller, C. J.; Rose, A. L.; Waite, T. D. Phthalhydrazide chemiluminescence method for determination of hydroxyl radical production: modifications and adaptations for use in natural systems. Anal. Chem. 2011, 83, 261-268.

(27) Tian, F.; Liu, C.; Zhang, D.; Fu, A.; Duan, Y.; Yuan, S.; Yu, J. C. On the Origin of the Visible - Light Activity of Titanium Dioxide Doped with Carbonate Species. ChemPhysChem 2010, 11, 3269-3272.

(28) Water quality determination of the acute toxicity luminescent bacteria test. GB/T15441-1995.

(29) An, T.; Fang, H.; Li, G.; Wang, S.; Yao, S. Experimental and theoretical insights into photochemical transformation kinetics and mechanisms of aqueous propylparaben and risk assessment of its degradation products. Environ. Toxicol. Chem. 2014, 33, 1809-1816.

(30) Heinlaan, M.; Ivask, A.; Blinova, I.; Dubourguier, H. C.; Kahru, A. Toxicity of nanosized and bulk $\mathrm{ZnO}, \mathrm{CuO}$ and $\mathrm{TiO}_{2}$ to bacteria Vibrio fischeri and crustaceans Daphnia magna and Thamnocephalus platyurus. Chemosphere 2008, 71, 1308-16.

(31) Kahru, A.; Kurvet, M.; Külm, I. Toxicity of phenolic wastewater to luminescent bacteria Photobacterium phosphoreum and activated sludges. Water Sci. Technol. 1996, 33, 139-146.

(32) Natalio, F.; Andre, R.; Hartog, A.; Stoll, B.; Jochum, K.; Wever, R.; Tremel, W. Vanadium pentoxide nanoparticles mimic vanadium haloperoxidases and thwart biofilm formation. Nat. Nanotechnol. 2012, $7,530-535$.

(33) Hirakawa, T.; Nosaka, Y. Properties of $\mathrm{O}_{2}{ }^{\bullet-}$ and $\mathrm{OH}$ formed in $\mathrm{TiO}_{2}$ aqueous suspensions by photocatalytic reaction and the influence of $\mathrm{H}_{2} \mathrm{O}_{2}$ and some ions. Langmuir 2002, 18, 3247-3254.

(34) Xu, Y.; Schoonen, M. A. The absolute energy positions of conduction and valence bands of selected semiconducting minerals. Am. Mineral. 2000, 85, 543-556.

(35) Zhang, Y.; Chen, Y.; Westerhoff, P.; Hristovski, K.; Crittenden, J. C. Stability of commercial metal oxide nanoparticles in water. Water Res. 2008, 42, 2204-12.

(36) Grätzel, M. Photoelectrochemical cells. Nature 2001, 414, 338 344.

(37) Butler, M.; Ginley, D. Prediction of flatband potentials at semiconductor - electrolyte interfaces from atomic electronegativities. J. Electrochem. Soc. 1978, 125, 228-232.

(38) Maurette, M. T.; Oliveros, E.; Infelta, P. P.; Ramsteiner, K.; Braun, A. M. Singlet oxygen and superoxide: experimental differentiation and analysis. Helv. Chim. Acta 1983, 66, 722-733.

(39) Aslam, M.; Ismail, I. M. I.; Salah, N.; Chandrasekaran, S.; Qamar, M. T.; Hameed, A. Evaluation of sunlight induced structural changes and their effect on the photocatalytic activity of $\mathrm{V}_{2} \mathrm{O}_{5}$ for the degradation of phenols. J. Hazard. Mater. 2015, 286, 127-135.

(40) González, G.; Sagarzazu, A.; Villalba, R. Study of the mechanochemical transformation of goethite to hematite by TEM and XRD. Mater. Res. Bull. 2000, 35, 2295-2308.

(41) Li, R.; Wang, X.; Jin, S.; Zhou, X.; Feng, Z.; Li, Z.; Shi, J.; Zhang, Q.; Li, C. Photo-induced $\mathrm{H}_{2}$ production from a $\mathrm{CH}_{3} \mathrm{OH}-\mathrm{H}_{2} \mathrm{O}$ solution at insulator surface. Sci. Rep. 2015, 5, 13475. 
(42) Gargantini, I. Further applications of circular arithmetic: Schroeder-like algorithms with error bounds for finding zeros of polynomials. SIAM J.Numer. Anal. 1978, 15, 497-510.

(43) Rossetto, A. L. de O. F.; Vicentini, D. S.; Costa, C. H.; Melegari, S. P.; Matias, W. G. Synthesis, characterization and toxicological evaluation of a core-shell copper oxide/polyaniline nanocomposite. Chemosphere 2014, 108, 107-114.

(44) Su, K.; Ai, Z.; Zhang, L. Efficient Visible Light-Driven Photocatalytic Degradation of Pentachlorophenol with $\mathrm{Bi}_{2} \mathrm{O}_{3} / \mathrm{TiO}_{2}-$ xBx. J. Phys. Chem. C 2012, 116, 17118-17123.

(45) Jiang, W.; Mashayekhi, H.; Xing, B. Bacterial toxicity comparison between nano-and micro-scaled oxide particles. Environ. Pollut. 2009, 157, 1619-1625.

(46) Qiu, T. A.; Gallagher, M. J.; Hudson-Smith, N. V.; Wu, J.; Krause, M. O.; Fortner, J. D.; Haynes, C. L. Research highlights: unveiling the mechanisms underlying nanoparticle-induced ROS generation and oxidative stress. Environ. Sci.: Nano 2016, 3, 940-945. 